\title{
Examining the Influence of Servant and Entrepreneurial Leadership on the Work Outcomes of Employees in Social Enterprises
}

\begin{abstract}
The present study examines the relative influence of two distinct leadership styles, servant leadership and entrepreneurial leadership, on the organizational commitment and innovative behavior of employees working in social enterprises. Analyzing data from 169 employees and 42 social entrepreneurs, we found that, although servant leadership was positively related to followers' organizational commitment, the relationship between entrepreneurial leadership and organizational commitment was insignificant. In contrast, whilst we found evidence that entrepreneurial leadership was positively related to followers' innovative behavior, the relationship between servant leadership and employees' innovative behavior was insignificant. Our research contributes to the underdeveloped literature on leadership in social enterprises by exploring the relative effectiveness of different leadership styles (namely an entrepreneurial leadership style and a servant leadership style) in promoting follower work attitudes and behaviors in social enterprises. In addition, our research demonstrates the importance of leadership over and above followers' individual differences such as pro-social motivation and creative self-efficacy.
\end{abstract}

Key Words: social enterprise; servant leadership; entrepreneurial leadership; organizational commitment; innovative behavior 


\section{Introduction}

Over the last decade, social entrepreneurship has emerged as an important cultural and economic phenomenon (Dacin, Dacin, \& Matear, 2010; Dacin, Dacin, \& Tracey, 2011). Social enterprises refer to organizations that engage in business to achieve social impact, whilst at the same time maintaining a focus on commercial objectives (Duniam \& Eversole, 2013). In other words, social enterprises are hybrid organizations that maintain both a social welfare logic and a commercial logic (Pache \& Santos, 2013).

Despite the growth of the social enterprise sector in both developed and emerging economies, there is increasing recognition that much more needs to be done to support its development. In particular, leadership has been cited as a critical factor which determines the success of social enterprises more specifically (Prabhu, 1999), and entrepreneurial ventures more generally (Kuratko, 2007). However, there is a lack of research on what constitutes effective leadership in social enterprises given their unique mix of social and commercial objectives.

Using data from 163 employees in 42 social enterprises across three countries, the present study makes a significant contribution by examining the relative influence of two distinctive but complementary styles of leadership on employees' innovative behavior and organizational commitment. More specifically, it focuses on entrepreneurial leadership, a leadership style which influences and directs followers towards the achievement of organizational goals that involve identifying and exploiting entrepreneurial opportunities (Renko, El Tarabishy, Carsrud, \& Brannback, 2015), and servant leadership, a leadership style which focuses on the development of followers and stresses to them the importance of serving others (Greenleaf, 2002). We chose to study these two leadership styles given the dual mission of social enterprises to serve the community and develop innovative products and services that will allow them to be commercially viable. In examining the relative 
influence of servant and entrepreneurial leadership, we argue that servant leadership will be more strongly related to the key work attitude of organizational commitment, given it focuses on the development of followers and serving the community, whilst entrepreneurial leadership will be more strongly related to innovative behavior, given it focuses on supporting followers to identify and exploit entrepreneurial opportunities. In doing so, we draw on social exchange and social learning theories to explain the effects of these different leadership styles.

Our research makes an important contribution to the literature by exploring the relative effectiveness of different leadership styles in promoting follower work attitudes and behaviors in social enterprises. In addition, our research demonstrates the importance of leadership over and above followers' individual differences such as pro-social motivation and creative self-efficacy (as studied in Grant, Dutton, \& Rosso, 2008; Tierney \& Farmer, 2002).

The present study also identifies a number of practical implications. By providing us with a greater understanding of which styles of leadership are more effective in promoting followers' work attitudes and behaviors in social enterprises, this research provides social entrepreneurs with knowledge of how to retain committed employees and ensure that they engage in innovative behavior in the workplace. In turn, these outcomes are likely to improve the sustainability of social enterprises.

\section{Theoretical Background}

\section{Social entrepreneurship}

Over the last few decades, social enterprise has emerged as a promising complement (and sometimes alternative) to both commercial and non-profit organizations (Borzaga \& Defourny, 2001), by leveraging capacities to deliver both economic and social value inherent in these more traditional organizational forms (Mair \& Marti, 2006; Liu, Takeda, \& Ko, 
2014). Historically, it has arisen from two distinct phenomena: non-profit organizations left exposed to withdrawal of government funding (Dart, 2004), and for-profit organizations' increased willingness to engage in social wealth creation projects (Thompson, 2002).

Whichever the source of funding, social enterprises have evolved as distinct from traditional businesses, not only through their pursuit of social outcomes, but also by placing these at the centre of the value creation processes that underpin their business models. Unlike conventional for-profit enterprises engaged in corporate social responsibility (CSR) initiatives, social enterprises do not just implement add-on voluntary social programs on the margin of their existing business activities. Instead of maintaining a dangerous separation between a favourable public image as good corporate citizen and an overriding profit motive driving their actual performance targets, as in the case of traditional businesses (Brammer \& Millington, 2005; Dauvergne \& LeBaron, 2014; Visser, 2011), they adopt a holistic social value oriented perspective integrated into the totality of their business activities. In other words, they seek inherently socially responsible ways of doing business. Typically, the stakeholder consultation often deemed sufficient in mainstream CSR is, for social enterprises, only a necessary condition for operating in a community. Consequently, social enterprises (such as Outlook Employment, Grameen Bank, or Benetech) have a significantly different business model DNA from their traditional counterparts (such as Adecco, Citibank, or Digital Book World). The place of social enterprises on a continuum between private profit and community welfare is represented in Figure 1.

Due to the challenges they pose to traditional business, social enterprises have most often been defined as innovative experiments with a double bottom line (financial and prosocial) in the social sector rather than the economic sector (Dart, 2004; Dees, 2007). Either way, social enterprise is increasingly being regarded as an economically viable solution to meet social needs neglected by traditional business approaches (Dart, 2004; Dees, 1998). 
Although there is disagreement in the literature over an adequate definition of social entrepreneurship (Roper \& Cheney, 2005), it has been argued that the distinctive feature of social entrepreneurship lies in the priority given to social wealth creation (Mair \& Marti, 2006). Yet, although social entrepreneurs focus on creating social value, they still need to have business skills in order to raise funds and develop innovative new products and services (Thompson, 2002).

Despite the recognized potential for complementary wealth creation, as hybrid forms of organization social enterprises face challenges of their own. To start with, their dual mission creates competing demands that are not always easily manageable. One such tension, more evident within shorter timeframes, is between the priority to be innovative (Thompson, Alvy, \& Lees, 2000; Liu, Eng, \& Takeda, 2013) and the need to serve wider stakeholder groups (Corner \& Ho, 2010; Liu et al., 2013). The main challenges faced by social entrepreneurs trying to both satisfy their stakeholders and be innovative in practising commercial entrepreneurship lie in the significantly different ways in which social entrepreneurs have to leverage on people, context, deal and opportunity (Austin, Stevenson, \& Wei-Skillern, 2006). These differences have prompted researchers (e.g., Phills, Deiglmeier, \& Miller, 2008; Dees, 2012) to redirect their focus from social enterprise as an organizational form to social entrepreneurship as a distinctive way of solving entrepreneurial problems. It is in this context that social innovation has been emphasized as the most important aspect of the performance of hybrid organizations such as social enterprises (Weerawardena \& Mort, 2006).

Notwithstanding this justified focus on social innovation, social enterprises are pressured to engage in dynamic revenue models that are often market-dependent, and therefore driven by market logics (Lepoutre, Justo, Terjesen, \& Bosma, 2013; Mair \& Marti, 2006). As the revenue model is (at least ideologically) pushed into the background, social 
enterprises tend to experience the traditional tensions between the operational and strategic levels of organizational management even more acutely than mainstream business organizations. One way forward and out of this impasse may lie in more intense stakeholder engagement (Smith \& Woods, 2015), to simultaneously ease the pressure on revenue dynamics and spur innovation in ways that increase the pool of social needs being satisfied.

The tension between the need to innovate and the expectation to serve more stakeholders has also been explained in terms of competing social welfare and commercial logics (Battilana \& Dorado, 2010; Pache \& Santos, 2013). Competing logics present social enterprise leaders with a difficult dilemma (Martin, 2003), and it is for this reason that organizations with a social mission must rely on leadership more than traditional organizations (Felício, Gonçalves, \& da Conceição Gonçalves, 2013). In such an institutional setting, where social enterprises face pressure to develop innovative new products and services, whilst at the same time serving a range of stakeholders in the community, leadership is of critical importance to organizational success.

Therefore, the present study investigates the relative influence of two distinct but complementary leadership styles on the attitudes and behaviors of employees working in social enterprises. More specifically, we argue that entrepreneurial leadership (Renko et al., 2015) will be more strongly related to work behaviors (e.g., innovative behavior), given its focus on directing followers towards the achievement of organizational goals that involve identifying and exploiting entrepreneurial opportunities, than servant leadership, which we argue will be more strongly related to follower work attitudes (e.g., organizational commitment), given its focus on follower development and support (Greenleaf, 2002). Although the effects of more traditional forms of leadership (e.g., transformational leadership) on innovative behavior and organizational commitment have been extensively studied in previous research (Avolio, Zhu, Koh, \& Puja, 2004; Hunter \& Cushenbury, 2011; 
Mumford \& Licuanan, 2004), recent critiques of transformational leadership have concluded that it has significant issues with conceptual and methodological validity (Knippenberg \& Sitkin, 2013). For example, scholars have argued that is incomplete due to the absence of a strong explicit moral dimension and that it does not focus explicitly on addressing the followers' needs but those of the organization more generally (Stone, Russell, \& Patterson, 2003). This led us to focus on more follower-centered forms of leadership, such as servant leadership and entrepreneurial leadership, which are better aligned to the focus of social enterprises than transformational leadership, in that they highlight the importance of serving others and developing innovative solutions to social problems. Recent meta-analytical work on transformational leadership suggests that people-centered forms of leadership (for example, servant leadership) are distinct constructs from transformational leadership and explain significant incremental variance in outcomes above and beyond transformational leadership (Hoch, Bommer, Dulebohn, \& Wu, 2016). Although entrepreneurial leadership and transformational leadership share commonalities, in that they focus on superior performance by appealing to the higher order needs of their employees (Gupta, MacMillan, \& Surie, 2004), the focus of entrepreneurial leaders on supporting followers to engage in opportunity-oriented behaviors distinguishes entrepreneurial leadership from transformational leadership.

\section{Servant leadership}

Although the concept of servant leadership was developed over 40 years ago by Greenleaf (1970), only in recent years has it begun to attract the attention of academics and practitioners. According to Greenleaf (1977), servant leadership is a style of leadership in which the leader is effectively a first among equals. As well as focusing on the development of followers and empowering followers through mentoring, servant leaders also stress the 
importance of creating value outside of the organization by working in the interest of those in the wider community (Ehrhart, 2004; Greenleaf, 1977; Liden, Wayne, Zhao, \& Henderson, 2008; Parris \& Welty Peachey, 2013; Sendjaya, Sarros, \& Santora, 2008; Stone, Russell, \& Patterson, 2003). For the purposes of this study we adopt Ehrhart's (2004) global measure of servant leadership, which highlights seven main behaviors exhibited by servant leaders: putting subordinates first, forming relationships with subordinates, helping subordinates to develop and succeed, having conceptual skills, empowering subordinates, behaving ethically, and creating value for those outside the organization. The findings of research indicate that servant leadership fosters more satisfied, committed, engaged and better-performing followers (Carter \& Baghurst, 2013; Liden et al., 2008; Mayer, Bardes, \& Piccolo, 2008; Neubert, Kacmar, Carlson, Chonko, \& Roberts, 2008). Social enterprises could be viewed as a fertile setting for the practice of servant leadership, as it is a setting in which entrepreneurs are more likely to focus on employee development and employees are able to have a more significant impact on the community through their work.

\section{Entrepreneurial leadership}

Entrepreneurial leadership has been defined as a leadership style in which leaders influence and direct their subordinates to identify and explore entrepreneurial opportunities (Renko et al., 2015). Entrepreneurial leaders not only support and encourage their subordinates to experiment and innovate in the workplace, but also act as role-models by engaging in entrepreneurial activity themselves. Although there is growing recognition of the importance of leadership in the entrepreneurial process (Chen, 2007; Gupta, MacMillan, \& Surie, 2004), limited work has examined the role of the effects of entrepreneurial leadership on follower work outcomes. Most of the work looking at the effects of entrepreneurial leadership has focused on its effects on firm-level outcomes (Chen, 2007; Huang, Ding, \& 
Chen, 2014). For example, Chen (2007) found that entrepreneurial leadership led to higher levels of creativity amongst top-management team members, which in turn promoted the innovative capability of new ventures. Similarly, Huang et al. (2014) found that entrepreneurial leadership resulted in greater exploratory and exploitative innovation in enterprises.

\section{Hypothesis Development}

\section{Leadership and affective organizational commitment}

In the present study, we first examine the relationship between both servant and entrepreneurial leadership and the affective organizational commitment of followers. Affective commitment refers to an employee's emotional attachment to and identification with the organization (Meyer, Allen, \& Smith, 1993). We chose to focus on affective organizational commitment as a focal work attitude because it has been shown by metaanalytical work to be a better predictor of key outcomes of benefit to organizations than other work attitudes (Meyer, Stanley, Herscovitch, \& Topolnytsky, 2002; Riketta, 2002).

Although organizational commitment has been studied in relation to leadership from a variety of perspectives, e.g., as mediated by organizational culture (Simosi \& Xenikou, 2010), influencing job satisfaction (Top, Akdere, \& Tarcan, 2015; Top \& Gider, 2013), or moderated by perceived organizational competence (Kim, Eisenberger, \& Baik, 2016), prior work has typically focused on transformational leadership. The effects of people-centered leadership approaches, such as entrepreneurial and servant leadership, which as highlighted earlier are more aligned to the mission of social enterprises, has received less attention from researchers. Although the relative effects of servant and entrepreneurial leadership on affective organizational commitment have yet to be studied, recent meta-analytical work 
established that servant leadership explained 15 percent of incremental variance beyond transformational leadership (Hoch, Bommer, Dulebohn, \& Wu, 2016).

In prior research, social exchange theory (Blau, 1964) has been invoked to explain why servant leadership enhances followers' organizational commitment (Miao, Newman, Schwarz, \& Xu 2014). As supervisors are perceived to be the face of the organization responsible for implementing organizational policy, the provision of positive treatment by supervisors is likely to lead followers to reciprocate in the form of improved work attitudes, such as organizational commitment. More specifically, the exhibition of key servant leadership behaviors, such as forming strong relationships with followers and helping them to develop and succeed, should lead followers to reciprocate through heightening their emotional attachment to and identification with the organization. Empirical research provides support for such assertions. For example, Miao et al. (2014) found a strong relationship between servant leadership and the affective commitment of civil servants in China. Similarly, Liden et al. (2008) found a strong relationship between servant leadership and the organizational commitment of employees in a commercial organization in the US. However, we expect the relationship between servant leadership and organizational commitment to be even stronger in social enterprises, given it is a style of leadership that fits with the mission of social enterprises, i.e., creating value for those outside the organization. As many employees are attracted to work in social enterprises for altruistic reasons (i.e., to give something back to society), they are likely to have congruent values with servant leaders who stress to employees the importance of practising a serving mentality outside the organization, and are therefore likely to respond more positively to servant leadership than workers in commercial organizations.

Although there is growing evidence of a positive relationship between servant leadership and employee work attitudes such as job satisfaction and organizational 
commitment (Liden et al., 2008; Miao et al., 2014; Schneider \& George, 2011), prior research has not examined the relationship between entrepreneurial leadership and organizational commitment. We might also expect a positive relationship between entrepreneurial leadership and affective commitment as followers reciprocate the provision of encouragement by the leader for them to act in an entrepreneurial manner (Renko et al., 2015).

However, we also argue that servant leadership will be more strongly related to organizational commitment than entrepreneurial leadership. Unlike entrepreneurial leaders, who predominantly focus their resources on supporting their followers to experiment and innovate in the workplace (Renko et al., 2015), servant leaders are more likely to focus on developing their followers in a more holistic manner through the provision of socioemotional support. For example, in addition to providing job-related support to followers, servant leaders also assist followers when they face difficulties in their personal lives (Liden et al., 2015). The above discussion leads us to the following hypotheses:

Hypothesis 1: Servant leadership is positively related to organizational commitment. Hypothesis 2: Entrepreneurial leadership is positively related to organizational commitment.

Hypothesis 3: Servant leadership is more strongly related to organizational commitment than entrepreneurial leadership.

\section{Leadership and innovative behavior}

In the present study we also examine the relationship between both servant and entrepreneurial leadership and followers' innovative behavior in the social enterprise sector. Innovative behavior refers to the generation and implementation of new and useful ideas by employees in the workplace (Scott \& Bruce, 1994). As well as being the source of around 80 percent of new ideas in the workplace (Getz \& Robinson, 2003), the successful 
implementation of new ideas within organizations requires the involvement of employees. Although growing work has examined the influence of more traditional styles of leadership, such as transformational leadership, on innovative behavior (see Aryee, Walumbwa, Zhou, \& Hartnell, 2012; Pieterse, van Knippenberg, Schippers, \& Stam, 2010), limited empirical studies have examined the influence of more people-centered forms of leadership, such as servant and entrepreneurial leadership, with the exception of Yoshida, Sendjaya, Hirst, and Cooper (2014). Building on this work, the present study examines the relative influence of both forms of leadership on followers' innovative behavior. Servant leadership is to be positively related to innovative behavior for at least two reasons: as well as promoting a climate of safety and security in which followers will be willing to put forward new ideas without fear of ridicule, servant leadership also fosters the collective effort of team members to implement such ideas in the workplace (Yoshida et al., 2014). Consequently, Yoshida et al. (2014) find a strong relationship between servant leadership and employee creativity, mediated by leader identification. We might also expect entrepreneurial leadership to be strongly related to followers' innovative behavior. In the present study, we draw on social learning theory (Bandura, 1977, 1986) to explain how entrepreneurial leaders enhance followers' innovative behavior in the workplace. Social learning theory postulates that individuals learn through observing and emulating others' attitudes and behaviors (Bandura, 1977). Leaders are an especially important source of role modelling due to their status as well as their ability to utilize organizational rewards to establish what behavior is expected (Miao et al., 2014). More specifically, through acting as entrepreneurial role models to their followers by identifying and exploiting new opportunities at work, entrepreneurial leaders highlight the importance of engaging in entrepreneurial behaviors in the workplace (Gupta et al., 2004; Renko et al., 2015). In addition to role modelling the behaviors expected from their followers, entrepreneurial leaders actively encourage their followers to engage in innovative 
behavior and stimulate them to think in more innovative ways (Gupta et al., 2004; Thornberry, 2006).

Although we expect both servant and entrepreneurial leadership to be positively related to followers' innovative behavior, we expect the relationship between entrepreneurial leadership and innovative behavior to be stronger than that between servant leadership and innovative behavior. We argue that this results from the fact that the advice, support and role modelling provided by entrepreneurial leaders focus more specifically on entrepreneurial behaviors than the more general support provided by servant leaders. In addition, some followers may not respond positively to the demands placed on them by the entrepreneurial leader to identify and exploit entrepreneurial opportunities in the workplace. The above discussion leads us to the following hypotheses:

Hypothesis 4: Servant leadership is positively related to innovative behavior.

Hypothesis 5: Entrepreneurial leadership is positively related to innovative behavior. Hypothesis 6: Entrepreneurial leadership will be more strongly related to innovative behavior than servant leadership.

\section{Method}

\section{Sample and procedures}

Data collection for our project was undertaken in late-2014 to mid-2015 across three countries: Australia, Canada and the UK. Given there was no government registry of social enterprises in Australia, Canada and the UK in 2014, we used publicly available information from the member directories of Social Traders Australia, Social Enterprise Canada and Social Enterprise UK to develop our own database of social enterprises. In our database we included all enterprises from these directories that provided the name of a lead social entrepreneur and a contactable e-mail address. This amounted to 3316 enterprises in Australia, 99 enterprises 
in Canada and 236 enterprises in the UK. We sent out an e-mail to each of the social entrepreneurs in the database, inviting them to participate in the study. In this e-mail we highlighted the purpose of the study and promised participants that their responses would be kept confidential. We informed them that, in order to participate in the study, the social enterprise should employ at least three individuals who report directly to the social entrepreneur.

When a social entrepreneur agreed to take part in our study, we mailed them a pack of questionnaires (a questionnaire for the social entrepreneurs and a set of five questionnaires for their direct reports). We instructed them to fill out the questionnaire that was designed for the social entrepreneur, and distribute the remaining questionnaires to 3-5 of their direct reports. As most of the approached social enterprises were small (most social entrepreneurs had five or fewer direct reports in their senior management team), the questionnaires were distributed to all direct reports, i.e., no selection was necessary. This also means that the risk of selection bias was negligible. Where the social entrepreneur of the respondent organisations had more than five reports, they were asked to randomly select direct reports. The questionnaires were coded to allow the research team to match entrepreneur and subordinate responses, and participants were asked to mail the questionnaire directly to the researchers on completion. In this way, confidentiality was ensured, as the social entrepreneurs did not have any opportunity to see any of their direct reports' responses. This procedure facilitated independence and reduced bias in employee responses.

Although 99 social entrepreneurs initially agreed to participate in our research, around half withdrew after the questionnaire packs had been sent. A total of 199 employees from 48 social enterprises returned questionnaires. However, as only 42 social entrepreneurs rated their subordinates' innovative behavior, we excluded employee data from six enterprises 
from our final sample. We also excluded employee responses where there was missing data on our main study variables. This left a final sample size that consisted of 169 employees.

The employees who participated in our study had on average worked for the social enterprises for 4.75 years and were on average around 41 years of age. Fifty-four percent of them were female. The social entrepreneurs who participated in the research study had been operating their social enterprises for just over six years on average and their average age was 51 years. Fifty-five percent of them were male. Of the social enterprises, around 32 percent operated in the business services industry, 15 percent in the disability services industry, 12 percent in the housing association industry, 10 percent in the hospitality/events industry, 10 percent in the community services industry and 2 percent in the health services industry.

\section{Measures}

For all measures, participants rated items using a 5-point Likert scale where $1=$ 'strongly disagree' and 5= 'strongly agree'.

\section{Entrepreneurial leadership}

The 8-item ENTRELEAD scale developed by Renko et al. (2015) was used by followers to rate the entrepreneurial leadership of the social entrepreneur. Sample items included 'My supervisor challenges and pushes me to act in a more innovative way' and 'My supervisor has creative solutions to problems'. The Cronbach's alpha for this scale was .86.

\section{Servant leadership}

Servant leadership of the social entrepreneurs was rated by followers using Ehrhart's (2004) 14-item scale. Sample items included 'My supervisor creates a sense of community 
among employees' and 'My supervisor makes the personal development of employees a priority'. The Cronbach's alpha for this scale was .91 .

\section{Affective organizational commitment}

The six-item scale developed by Meyer and Allen (1993) was used to measure affective organizational commitment. Sample items included 'I would be very happy to spend the rest of my career at this organization'. The Cronbach's alpha for this scale was .88 .

\section{Innovative behavior}

Five items from Scott and Bruce's (1994) 6-item scale were used by social entrepreneurs to rate the innovative behavior of their followers. Sample items include 'This employee searches out new technologies, processes, techniques, and/or ideas' and 'This employee generates creative ideas'. One item from the original scale, 'This employee investigates and secures funds needed to implement new ideas', was excluded, as employees are rarely required to seek funding for the implementation of new ideas in the social enterprise sector. The Cronbach's alpha for this scale was .91.

\section{Control variables}

Follower tenure at the social enterprise (measured in years), follower age (measured in years), follower gender ( coded $1=$ male, $0=$ female $)$ and origin $(1=\mathrm{UK}, 2=$ Canada and 3 = Australia) were included as controls. We also controlled for followers' pro-social motivation, as this has been shown to exert a strong influence on employee work attitudes (Grant et al., 2008; Kjeldsen \& Andersen, 2013), and it is salient in this context, given that social enterprises provide employees with the opportunity to make a difference. An adapted version of the 4-item scale developed by Grant (2008) was used by followers to rate their pro- 
social motivation. Sample items included 'I am motivated to do my work because I care about benefiting others through my work' and 'I am motivated to do my work because I want to have positive impact on others'. The Cronbach's alpha for this scale was .92. Finally, we controlled for followers' creative self-efficacy, as this has been found to be an important antecedent of employee creativity in the workplace, a key dimension of innovative behavior (Tierney \& Farmer, 2002; Tierney \& Farmer, 2011). Creative self-efficacy was measured using the 4-item scale developed by Tierney and Farmer (2002). Sample items included 'I have confidence in my ability to solve problems creatively' and 'I feel that I am good at generating novel ideas'. The Cronbach's alpha for this scale was .89.

\section{Results}

Table 1 reports means, standard deviations and correlations amongst the study variables. Given that age, gender and origin were not correlated with the outcomes (i.e., affective commitment and innovative behavior), we decided not to incorporate these demographic variables as controls when testing our hypotheses in order to avoid biased parameter estimates (cf. Becker, 2005).

[Table 1 here]

\section{Construct validity of measurement model}

Before hypothesis testing was undertaken, confirmatory factor analysis (CFA) was conducting using AMOS version 22 in order to determine the construct validity of study variables. The six-factor model (i.e., servant leadership, entrepreneurial leadership, pro-social motivation, creative self-efficacy, affective organizational commitment and innovative behavior) yielded a good fit to the data $\left(\chi^{2}(d f=764)=1314.73, \mathrm{IFI}=.95, \mathrm{CFI}=.95\right.$, RMSEA $=.066$, SRMR $=.072)$. These statistics meet the recommendations of researchers 
(Browne \& Cudeck, 1992; Kline, 2005), who have argued that a satisfactory model fit can be inferred when CFI is greater than .90 and the RMSEA and SRMR are lower than .08 .

The six-factor measurement model was then compared to a series of alternative models to provide further evidence of construct validity. A five-factor model, in which servant and entrepreneurial leadership were loaded onto a single factor, resulted in poorer fit $\left(\chi^{2}(d f=769)=1557.52, \mathrm{IFI}=.94, \mathrm{CFI}=.94, \mathrm{RMSEA}=.078, \mathrm{SRMR}=.076\right)$, as did a fivefactor model in which pro-social motivation and creative self-efficacy were loaded onto a single factor $\left(\chi^{2}(d f=769)=1931.26, \mathrm{IFI}=.91, \mathrm{CFI}=.91, \mathrm{RMSEA}=.095, \mathrm{SRMR}=.11\right)$. Finally, a one-factor model in which all study items were loaded onto a single factor resulted in extremely poor fit $\left(\chi^{2}(d f=779)=4071.41, \mathrm{IFI}=.79, \mathrm{CFI}=.79, \mathrm{RMSEA}=.16, \mathrm{SRMR}\right.$ $=.14)$. Together these results highlight adequate discriminant and convergent validity of the study variables.

Given that 169 employees provided ratings of entrepreneurial leadership and servant leadership for 42 social entrepreneurs, we conducted ANOVA and intra-class correlation (ICC) tests to ensure that non-independence of observations was not related to differences in employees' rating patterns for each entrepreneur (Bliese, 2000). The ANOVA was significant $(\mathrm{F}=2.48, \mathrm{p}<.01)$, and the ICC (1) and ICC (2) results for entrepreneurial leadership were 0.25 and 0.59 , and $=2.48, \mathrm{p}<.01)$. Furthermore, the ANOVA was also significant $(\mathrm{F}=2.00$, $\mathrm{p}<.01)$. and the ICC (1) and ICC (2) results for servant leadership were 0.18 and 0.50 , and $=$ $2.48, \mathrm{p}<.01)$. Although the ANOVA results of both leadership styles were significant, the ICC (2) of both leadership styles was slightly lower than the recommended threshold of ICC (2) $>0.60$ (Bliese, 2000). While the average group size and the overall sample size were relatively small and ICC 2 was very sensitive to the sample size, we could aggregate entrepreneurial leadership and servant leadership as group-level constructs for subsequent analyses (Bliese, 2000). In addition, we performed inter-rater reliability tests to assess the 
level of inter-rater agreement for servant leadership and entrepreneurial leadership within each business (James, Demaree, \& Wolf, 1984). The median $r_{w g(j)}$ of servant leadership was . 99, and entrepreneurial leadership was .98. Given both values were higher than the recommended levels (James et al., 1984), the $r_{w g(j)}$ results provide support for the group-level aggregation.

Taking the ICC and $r_{w g(j)}$ results together, we aggregated entrepreneurial leadership and servant leadership as group-level constructs for subsequent analyses using SPSS mixed modelling. Mixed modelling is designed to analyse nested data (e.g., individuals' responses nested in teams) collected from a small sample size, because it is less sensitive to group size (Verbeke, \& Molenberghs, 2000).

\section{Hypothesis testing}

Hypotheses were tested using mixed modelling of hierarchical regression analysis in SPSS 20. To reduce problems associated with multicollinearity in moderated regression, all variables were Z-standardized prior to analysis (Tabachnick \& Fidell, 2013). Evaluation of regression assumptions of normality, linearity, and absence of multicollinearity was checked and their results met recommended standards.

The results of analysis are presented in Table 2 for both followers' affective organizational commitment (Models 1 and 2) and followers' innovative behavior (Models 3 and 4). Initially, the control variables (tenure, age, gender, pro-social motivation and creative self-efficacy) were entered into the first step of the regression (Models 1 and 3). Of all the control variables, only tenure $(\beta=.04, \mathrm{p}<.01)$ and pro-social motivation $(\beta=.40, \mathrm{p}<.01)$ were positively related to affective organizational commitment in Model 1, and only creative self-efficacy $(\beta=.20, \mathrm{p}<.05)$ was positively related to innovative behavior in Model 3 . 
Following this, both independent variables were entered into the second step of the regression. The results in Models 1 and 2 of Table 2 reveal that only servant leadership ( $\beta$ $=.47, \mathrm{p}<.01)$ but not entrepreneurial leadership $(\beta=.13, \mathrm{n} . \mathrm{s})$ was found to be positively related to followers' affective organizational commitment. These results provide support for Hypotheses 1 and 3, but Hypothesis 2 is not supported. With respect to Hypotheses 4 to 6, the results of Models 3 and 4 in Table 2 show that entrepreneurial leadership was positively related to followers' innovative behavior $(\beta=.35, \mathrm{p}<.01)$ but servant leadership was not related to followers' innovative behavior $(\beta=-.22, \mathrm{n} . \mathrm{s})$. These results provide support for Hypotheses 4 and 6, but Hypothesis 5 is not supported. To ensure that the results presented in Table 2 were not confounded by the order of both servant leadership and entrepreneurial leadership being entered into the regression analyses, we also conducted additional analyses by changing the order of entering both leadership styles into the regression equation. Results are reported in Table 3. In general, results presented Tables 2 and 3 showed a consistent pattern, confirming the unique differential impact exerted by both leadership styles on different outcomes. Our findings suggest that servant leadership more strongly predicts followers' affective organizational commitment than entrepreneurial leadership, but that entrepreneurial leadership more strongly predicts followers' innovative behavior than servant leadership.

\section{Discussion}

The present study makes an important theoretical and empirical contribution by examining the role played by servant and entrepreneurial leadership in enhancing the organizational commitment and innovative behavior of employees in social enterprises, whilst controlling for employees' pro-social motivation and creative self-efficacy (Grant et al., 2008; Tierney \& Farmer, 2002). Our findings revealed that, whilst servant leadership 
predicted followers' affective organizational commitment, the relationship between entrepreneurial leadership and followers' affective organizational commitment was insignificant. In contrast, whilst our results revealed that entrepreneurial leadership was positively related to followers' innovative behavior, the relationship between servant leadership and followers' innovative behavior was insignificant.

The strong association found between servant leadership and followers' affective organizational commitment confirms the findings of prior empirical work on servant leadership in China and the USA (Miao et al., 2014; Liden et al., 2008). This is also consistent with the tenets of social exchange theory (Blau, 1964), which predicts that employees will reciprocate the provision of positive treatment by their supervisors in the form of improved work attitudes. More specifically, our findings suggest that the display of key servant leadership behaviors, such as forming strong relationships with followers and helping them to develop and succeed, leads followers to reciprocate through higher levels of affective commitment. The lack of a significant relationship between entrepreneurial leadership and affective commitment was contrary to what was hypothesized. Such a finding may result from the fact that all followers may not respond positively to the demands placed on them by the entrepreneurial leader to identify and exploit entrepreneurial opportunities in the workplace. Whereas some followers may respond positively to such demands, others may find them stressful. Future research should seek to identify the groups of employees that may respond positively to entrepreneurial leadership in terms of enhanced affective commitment. Our findings build on previous work by showing that servant leadership, in addition to transformational leadership, is effective in predicting followers' affective organizational commitment (Top, Akdere, \& Tarcan, 2015).

Although our findings are consistent with social learning theory (Bandura ,1977), as they demonstrate that the role modelling provided by entrepreneurial leaders will lead 
followers to be more innovative at work, they are inconsistent with those of prior empirical research that found a positive relationship between servant leadership and employee creativity (Yoshida et al., 2014). For the negative but marginally insignificant relationship identified between servant leadership and innovative behavior, two explanations may be provided. First, as highlighted by Yoshida et al. (2014), their work failed to control for other leadership styles. By measuring the relative importance of different leadership behaviors, the present study allows us to distinguish the unique effects of different leadership styles on innovative behavior better than does previous research. Second, given that individuals generally choose to work for social enterprises to make a significant contribution to society, the encouragement provided by servant leaders to create value for those outside the organization may lead followers to focus more on serving others rather than developing innovative new products and services.

Given the pressures faced by social enterprises to be innovative (Thompson et al., 2000; Liu et al., 2013), whilst also serving the needs of wider stakeholder groups (Corner \& Ho, 2010; Liu et al., 2012), our findings make a significant contribution by providing us with a detailed understanding of the relative effectiveness of different styles of leadership in promoting employees' work attitudes and behaviors in the social enterprise sector. These findings suggest that entrepreneurs should take a balanced approach to leadership; i.e., focus on building strong relationships with followers through the provision of support, whilst at the same time acting as entrepreneurial role models to them.

\section{Conclusion}

With regard to managerial implications, key practical implications emerge from these findings for social entrepreneurs looking to enhance employee work attitudes and behavior in order to improve the overall effectiveness of their enterprises. By providing a detailed 
understanding of the unique effects of entrepreneurial leadership and servant leadership respectively, and of when to exhibit these different styles appropriately, social entrepreneurs are better able to determine which leadership styles they can use to promote the affective organizational commitment and, respectively, the innovative behavior of employees.

Our findings also support the thesis that no single leadership style is effective for all situations they need to manage at work, because the effects of different leadership styles can be outcome-specific (Tse \& Chiu, 2014). Specifically, it is suggested that, if social entrepreneurs wish to encourage innovative behavior amongst their followers, they should consider adopting an entrepreneurial style of leadership in which they act as an entrepreneurial role model and encourage their followers to act entrepreneurially. On the other hand, if social entrepreneurs aim for more committed employees who are less likely to leave the organization, they should act as servant leaders to their followers by encouraging them, in leading by example, to create value for those outside the organization. However, at the same time social entrepreneurs should realize that the two styles are not mutually exclusive, given a high correlation between both styles of leadership i.e., they can act as entrepreneurial leaders whilst at the same time acting as servants to their followers.

Knowledge of the potential of the entrepreneurial and servant leadership styles to influence organizational commitment and innovative behavior is very useful to human resource managers as well, as they need to reconsider the criteria used for recruiting, selecting, training, developing and promoting workplace leaders capable of stimulating organizational commitment and innovative behaviors in social enterprise employees.

Concerning limitations of this study and suggestions for future research, one such limitation is that it did not measure potential mediators of the relationship between different leadership styles and follower work outcomes. In order to confirm the proposed theoretical mechanisms linking both servant and entrepreneurial leadership to organizational 
commitment and innovative behavior, future empirical research might include mediators which capture social exchange and social learning processes.

A further limitation arises from the fact that, although the independent and dependent variables in the study were collected from different sources, they were collected at the same point in time. This limits our ability to determine a causal relationship between leadership and the work outcomes in our study. In order to provide more robust findings around the influence of different styles of leadership on organizational commitment and innovative behavior, future research should ensure that the independent and dependent variables are collected at different time periods.

To summarize, in this study we examined the relative influence of two distinct leadership styles, servant leadership and entrepreneurial leadership, on the organizational commitment and innovative behavior of employees working under social entrepreneurs. We found that, although both styles of leadership were positively related to followers' organizational commitment, the relationship between servant leadership and organizational commitment was stronger than that between entrepreneurial leadership and organizational commitment. In contrast, whilst we found evidence that entrepreneurial leadership was positively related to the innovative behavior of followers, the relationship between servant leadership and innovative behavior was insignificant. These findings are consistent with both social exchange and social learning theories, in that they provide us with a detailed understanding as to which styles of leadership are effective in promoting followers' work attitudes and behaviors. This is especially important, given that social enterprises operate in an institutional context where they are faced with having to focus on serving the community while at the same time developing innovative new products and services. 


\section{References}

Aryee, S., Walumbwa, F. O., Zhou, Q., \& Hartnell, C. A. (2012). Transformational leadership, innovative behavior, and task performance: Test of mediation and moderation processes. Human Performance, 25, 1-25.

Austin, J., Stevenson, H., \& Wei-Skillern, J. (2006). Social and commercial entrepreneurship: Same, different, or both? Entrepreneurship, Theory and Practice, 30, 1-22.

Avolio, B. J., Zhu, W., Koh, W., \& Puja, B. (2004). Transformational leadership and organizational commitment: Mediating role of psychological empowerment and moderating role of structural distance. Journal of Organizational Behavior, 25, 951968.

Bandura, A. (1977). Social learning theory. Englewood Cliffs, NJ: Prentice-Hall.

Bandura, A. (1986). Social foundations of thought and action: A social cognitive theory. Englewood Cliffs, NJ: Prentice-Hall.

Battilana, J., \& Dorado, S. (2010). Building sustainable hybrid organizations: The case of commercial microfinance organizations. Academy of Management Journal, 6, 14191440.

Blau, P. M. (1964). Exchange and power in social life, New York, NY: Wiley.

Bliese, P. (2000). Within-group agreement, non-independence, and reliability. In K. Klein \& S. Kozloweski (Eds.), Multi-level theory, research, and methods in organizations (pp. 349-381. San Francisco, CA: Jossey-Bass.

Borzaga, C., \& Defourny, J. (2001). The emergence of social enterprise (Vol. 4). Hove, UK: Psychology Press.

Brammer, S., \& Millington, A. (2005). Corporate reputation and philanthropy: An empirical analysis. Journal of Business Ethics, 61(1), 29-44. 
Browne, M. W., \& Cudeck, R. (1992). Alternative ways of assessing model fit. Sociological Methods and Research, 21, 230-258.

Carter, D., \& Baghurst, T. (2013). The influence of servant leadership on restaurant employee engagement. Journal of Business Ethics, 124, 453-464.

Chen, M.H. (2007). Entrepreneurial leadership and new ventures: Creativity in entrepreneurial teams. Creativity and Innovation Management, 16, 239-249.

Corner, P. D., \& Ho, M. (2010). How opportunities develop in social entrepreneurship. Entrepreneurship, Theory and Practice, 34, 635-659.

Dacin, P. A., Dacin, M. T., \& Matear, M. (2010). Social entrepreneurship: Why we don't need a new theory and how we move forward from here. Academy of Management Perspectives, 24, 37-57.

Dacin, P. A., Dacin, M. T., \& Tracey, P. (2011). Social entrepreneurship: A critique and future directions. Organization Science, 22, 1203-1213.

Dart, R. (2004). The legitimacy of social enterprise. Nonprofit Management and Leadership, 14, 411-424.

Dauvergne, P., \& LeBaron, G. (2014). Protest Inc: The corporatization of activism. Cambridge: Polity Press.

Dees, J. (1998). Enterprising nonprofits. Harvard Business Review, Jan-Feb, 55-67.

Dees, J. (2007). Taking social entrepreneurship seriously. Society, 44, 24-31.

Dees, J. (2012). A tale of two cultures: Charity, problem solving, and the future of social entrepreneurship. Journal of Business Ethics, 111, 321-334.

Ehrhart, M. G. (2004). Leadership and procedural justice climate as antecedents of unit-level organizational citizenship behavior. Personnel Psychology, 57, 61-94.

Emerson, J., \& Twersky, F. (1996). New social entrepreneurs: The success, challenge, and lessons of non-profit enterprise creation. San Francisco, CA: Roberts Foundation. 
Felício, J. A., Gonçalves, H. M., \& da Conceição Gonçalves, V. (2013). Social value and organizational performance in non-profit social organizations: Social entrepreneurship, leadership, and socioeconomic context effects. Journal of Business Research, 66, 2139-2146.

Getz, I., \& Robinson, A. G. (2003). Innovate or die: Is that a fact? Creativity and Innovation Management, 12, 130-136.

Grant, A. M. (2008). Does intrinsic motivation fuel the prosocial fire? Motivational synergy in predicting persistence, performance, and productivity. Journal of Applied Psychology, 93, 48-58.

Grant, A. M., Dutton, J. E., \& Rosso, B. D. (2008). Giving commitment: Employee support programs and the prosocial sensemaking process. Academy of Management Journal, $51,898-918$.

Greenleaf, R. K. (1970). The servant as leader. Indianapolis, IN: The Robert K. Greenleaf Center.

Greenleaf, R. K. (1977). Servant leadership: A journey into the nature of legitimate power and greatness. New York, NY: Paulist Press.

Greenleaf, R. K. (2002). Servant leadership: A journey into the nature of legitimate power and greatness (25th anniversary edition). New York, NY: Paulist Press.

Gupta, V., MacMillan, I. C., \& Surie, G. (2004). Entrepreneurial leadership: Developing and measuring a cross-cultural construct. Journal of Business Venturing, 19, 241-260.

Hoch, J. E., Bommer, W. H., Dulebohn, J. H., \& Wu, D. (2016). Do ethical, authentic and servant leadership explain variance above and beyond transformational leadership? A meta-analysis. Journal of Management, in press.

Huang, S., Ding, D., \& Chen, Z. (2014). Entrepreneurial leadership and performance in Chinese new ventures: A moderated mediation model of exploratory innovation, 
exploitative innovation and environmental dynamism. Creativity and Innovation Management, 23, 453-471.

Hunter, S. T., \& Cushenbery, L. (2011). Leading for innovation: Direct and indirect influences. Advances in Developing Human Resources, 13, 248-265.

James, L. R., Demaree, R. G., \& Wolf, G. (1984). Estimating within-group inter-rater reliability with and without response bias. Journal of Applied Psychology, 69, 86-98.

Kim, K. Y., Eisenberger, R., \& Baik, K. (2016). Perceived organizational support and affective organizational commitment: Moderating influence of perceived organizational competence. Journal of Organizational Behavior, 37, 558-583.

Kjeldsen, A. M., \& Andersen, L. B. (2013). How pro-social motivation affects job satisfaction: An international analysis of countries with different welfare state regimes. Scandinavian Political Studies, 36, 153-176.

Kline, R. (2005). The principles and practices of structural equation modeling. New York, NY: The Guilford Press.

Kuratko, D. F. (2007). Entrepreneurial leadership in the 21st Century. Journal of Leadership and Organizational Studies, 13, 1-11.

Lepoutre, J., Justo, R., Terjesen, S., \& Bosma, N. (2013). Designing a global standardized methodology for measuring social entrepreneurship activity: The global entrepreneurship monitor social entrepreneurship study. Small Business Economics, 40, 693-714.

Liden, R. C., Wayne, S. J., Zhao, H., \& Henderson, D. (2008). Servant leadership: Development of a multidimensional measure and multilevel assessment. Leadership Quarterly, 19, 161-177. 
Liu, G., Eng, T. Y., \& Takeda, S. (2013). An investigation of marketing capabilities and social enterprise performance in the UK and Japan. Entrepreneurship, Theory and Practice, 39, 267-298.

Liu, G., Takeda, S., \& Ko, W. W. (2014). Strategic orientation and social enterprise performance. Nonprofit and Voluntary Sector Quarterly, 43, 480-501.

Mair, J., \& Marti, I. (2006). Social entrepreneurship research: A source of explanation, prediction, and delight. Journal of World Business, 41, 36-44.

Martin, R. (2003). To the rescue: Beating the heroic leadership trap. Stanford Social Innovation Review, Winter, 36-43.

Mayer, D. M., Bardes, M., \& Piccolo, R. F. (2008). Do servant-leaders help satisfy follower needs? An organizational justice perspective. European Journal of Work and Organizational Psychology, 17, 180-197.

Meyer, J. P., Allen, N. J., \& Smith, C. A. (1993). Commitment to organizations and occupations: Extension and test of a three-component conception. Journal of Applied Psychology, 78, 538-551.

Meyer, J. P., Stanley, D. J., Herscovitch, L., \& Topolnytsky, L. (2002). Affective, continuance, and normative commitment to the organization: A meta-analysis of antecedents, correlates, and consequences. Journal of Vocational Behavior, 61, 2052.

Miao, Q., Newman, A., Schwarz, G., \& Xu, L. (2014). Servant leadership, trust, and the organizational commitment of public sector employees in China. Public Administration, 92, 727-743.

Mumford, M. D., \& Licuanan, B. (2004). Leading for innovation: Conclusions, Issues, and directions. The Leadership Quarterly, 15, 163-171. 
Neubert, M. J., Kacmar, K. M., Carlson, D. S., Chonko, L. B., \& Roberts, J. A. (2008). Regulatory focus as a mediator of the influence of initiating structure and servant leadership on employee behavior. Journal of Applied Psychology, 93, 1220-1233.

Pache, A. C., \& Santos, F. (2013). Inside the hybrid organization: Selective coupling as a response to conflicting institutional logics. Academy of Management Journal, 56, $972-1001$

Parris, D. L., \& Welty Peachey, J. (2013). A systematic literature review of servant leadership theory in organizational contexts. Journal of Business Ethics, 113, 377393.

Phills, J. A., Deiglmeier, K., \& Miller, D. T. (2008). Rediscovering social innovation. Stanford Social Innovation Review, 6, 34-43.

Pieterse, A. N., van Knippenberg, D., Schippers, M., \& Stam, D. (2010). Transformational and transactional leadership and innovative behavior: The moderating role of psychological empowerment. Journal of Organizational Behavior, 31, 609-623.

Prabhu, G. N. (1999). Social entrepreneurial leadership. Career Development International, 4, 140-145.

Renko, M., El Tarabishy, A., Carsrud, A. L., \& Brannback, M. (2015). Understanding and measuring entrepreneurial leadership style. Journal of Small Business Management, $53,54-74$.

Riketta, M. (2002). Attitudinal organizational commitment and job performance: A metaanalysis. Journal of Organizational Behavior, 23, 257-266.

Roper, J., \& Cheney, G. (2005). Leadership, learning, and human resource management: The meaning of social entrepreneurship today. Corporate Governance, 5, 95-104. 
Schneider, S. K., \& George, W. M. (2011). Servant leadership versus transformational leadership in voluntary service organizations. Leadership and Organization Development Journal, 32, 60-77.

Scott, S. G., \& Bruce, R. A. (1994). Determinants of innovative behavior: A path model of individual innovation in the workplace. Academy of Management Journal, 37, 580 607.

Sendjaya, S., Sarros, J. C., \& Santora, J. C. (2008). Defining and measuring servant leadership behavior in organizations. Journal of Management Studies, 45, 402-424.

Simosi, M., \& Xenikou, A. (2010). The role of organizational culture in the relationship between leadership and organizational commitment: An empirical study in a Greek organization. , The International Journal of Human Resource Management, 21, 15981616.

Smith, L., \& Woods, C. (2015). Stakeholder engagement in the social entrepreneurship process: Identity, governance and legitimacy. Journal of Social Entrepreneurship, 6, $186-217$.

Social Traders (2016). What is a social enterprise? Melbourne: Social Traders. Retrieved 3 January 2016 from http://www.socialtraders.com.au/about-social-enterprise/what-is-asocial-enterprise/social-enterprise-spectrum/.

Stone, A. G., Russell R. F., \& Patterson, K. (2004). Transformational vs servant leadership: A difference in leader focus. Leadership and Organisation Development Journal, 25, 349-361.

Tabachnick, B. G., \& Fidell, L. S. (2013). Using multivariate statistics. Boston, MA: Pearson.

Thompson, J. L. (2002). The world of the social entrepreneur. International Journal of Public Sector Management, 15, 412-431. 
Thompson, J., Alvy, G., \& Lees, A. (2000). Social entrepreneurship: A new look at the people and the potential. Management Decision, 38, 328-338.

Thornberry, N. (2006). Lead like an entrepreneur: Keeping the entrepreneurial spirit alive within the corporation. Fairfield, PA: McGraw Hill.

Tierney, P., \& Farmer, S. M. (2002). Creative self-efficacy: Its potential antecedents and relationship to creative performance. Academy of Management Journal, 45, 11371148.

Tierney, P., \& Farmer, S. M. (2011). Creative self-efficacy development and creative performance over time. Journal of Applied Psychology, 96, 277-293.

Top, M., \& Gider, Ö. (2013). Interaction of organizational commitment and job satisfaction of nurses and medical secretaries in Turkey. International Journal of Human Resource Management, 24, 667-683.

Top, M., Akdere, M., \& Tarcan, M. (2015). Examining transformational leadership, job satisfaction, organizational commitment, organizational trust in Turkish hospitals: Public servants versus private sector employees. International Journal of Human Resource Management, 26, 1259-1282.

Tracey, P., \& Jarvis, O. (2006). An enterprising failure: Why a promising social enterprise collapsed. Stanford Social Innovation Review, Spring, 66-70.

Tracey, P., \& Phillips, N. (2007). The distinctive challenge of educating social entrepreneurs: A postscript and rejoinder to the Special Issue on entrepreneurship education. Academy of Management Learning and Education, 6, 264-271.

Tse, H. H. M., \& Chiu, C. K. (2014). Transformational leadership and job performance. A social identity perspective. Journal of Business Research, 67, 2827-2835.

Weerawardena, J., \& Mort, G. S. (2006). Investigating social entrepreneurship: A multidimensional model. Journal of World Business, 41, 21-35. 
Van Knippenberg, D., \& Sitkin, S. B. (2013). A critical assessment of charismatictransformational leadership research: Back to the drawing board? The Academy of Management Annals, 7, 1-60.

Verbeke, G., \& Molenberghs, G. (2000). Linear mixed models for longitudinal data. New York, NY: Springer Verlag.

Visser, W. (2011). The age of responsibility: CSR 2.0 and the new DNA of business. Journal of Business Systems, Governance and Ethics, 5, 7-22.

Yoshida, D., Sendjaya, S., Hirst, G., \& Cooper, B. (2014). Does servant leadership foster creativity and innovation? A multi-level mediation study of identification and prototypicality. Journal of Business Research, 67, 1395-1404. 
Figure 1: The position of social enterprises on a community benefit to personal profit continuum (Source: Social Traders, 2016)

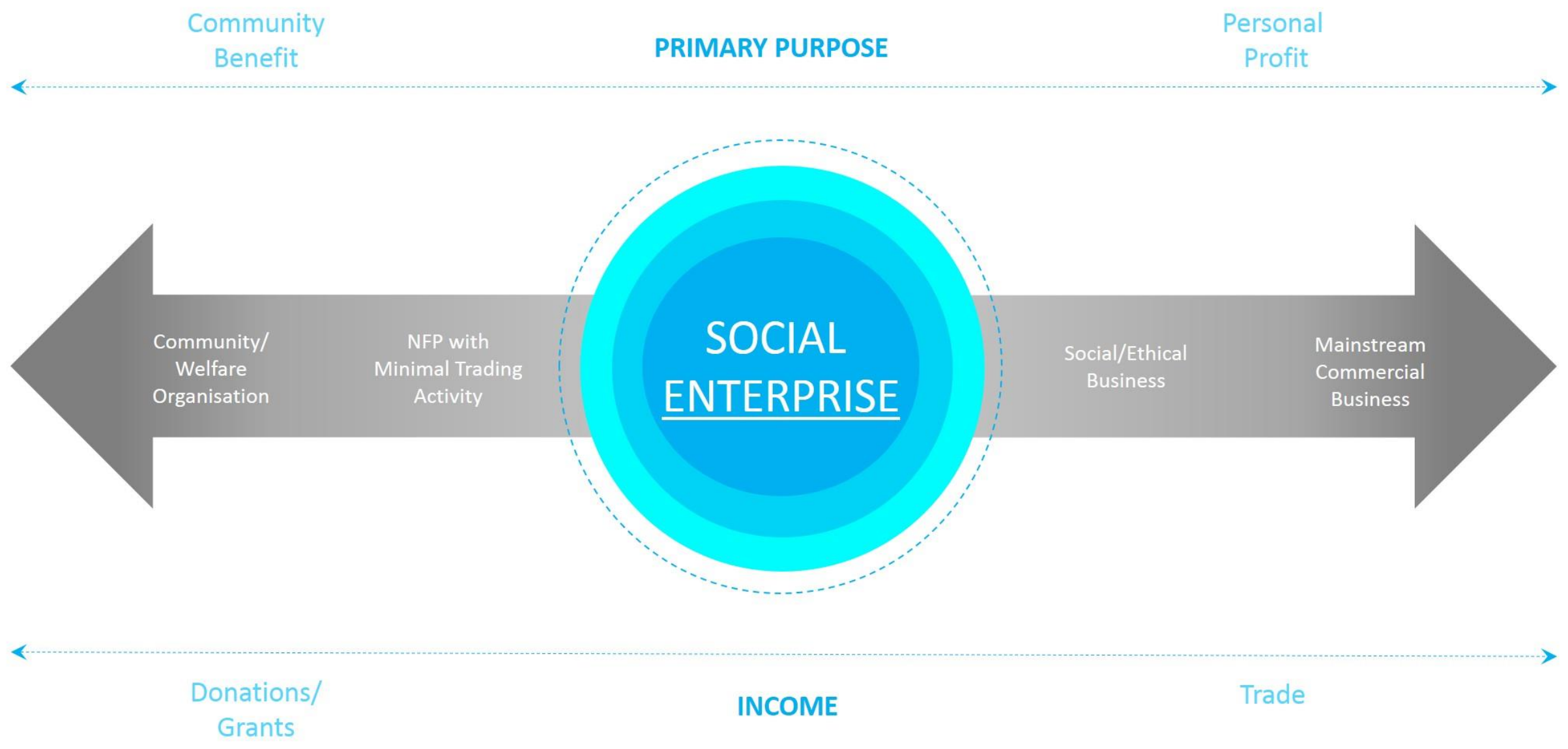


Table 1: Means, Standard Deviations, and Correlations among the Study Variables

\begin{tabular}{|c|c|c|c|c|c|c|c|c|c|c|c|c|}
\hline \multicolumn{2}{|c|}{ Variable } & $M$ & $S D$ & 1 & 2 & 3 & 4 & 5 & 6 & 7 & 8 & 9 \\
\hline 1 & Tenure & 4.75 & 5.24 & & & & & & & & & \\
\hline 2 & Age & 40.60 & 12.02 & $.33^{* *}$ & & & & & & & & \\
\hline 3 & Gender & 0.54 & .50 & -.12 & -.06 & & & & & & & \\
\hline 4 & Entrepreneurial leadership & 4.01 & .63 & -.01 & -.09 & -.08 & & & & & & \\
\hline 5 & Servant leadership & 4.00 & .62 & .05 & -.05 & $-.16^{*}$ & $.69^{* *}$ & & & & & \\
\hline 6 & Pro-social motivation & 4.28 & .63 & .06 & -.03 & .13 & $.21^{* *}$ & $.25^{* *}$ & & & & \\
\hline 7 & Creative self-efficacy & 4.01 & .68 & .01 & .02 & -.11 & .08 & .10 & $.21^{* *}$ & & & \\
\hline 8 & Affective commitment & 3.94 & .77 & $.29^{* *}$ & .06 & -.12 & $.45^{* *}$ & $.54^{* *}$ & $.39^{* *}$ & .13 & & \\
\hline 9 & Innovative behavior & 3.91 & .79 & -.06 & -.00 & .04 & .22 & .04 & -.01 & $.16^{*}$ & .07 & \\
\hline
\end{tabular}

$* p<.05, * * p<.01$. 
Table 2: Results of Hierarchical Regression Analyses (Mixed Modelling)

\begin{tabular}{lllll}
\hline & \multicolumn{2}{l}{$\begin{array}{l}\text { Affective Organizational } \\
\text { Commitment }\end{array}$} & Innovative Behavior \\
& Model 1 & Model 2 & Model 3 & Model 4 \\
\hline Tenure & $.04^{* *}$ & $.04^{* *}$ & -.01 & -.01 \\
Age & -.07 & .00 & .06 & .02 \\
Gender & -.16 & -.04 &.-01 & .05 \\
Pro-social motivation & $.40^{* * *}$ & $.27^{* *}$ & -.14 & -.16 \\
Creative self-efficacy & .05 & .04 & $.20^{*}$ & $.21^{*}$ \\
Servant leadership & & $.47^{* *}$ & & -.22 \\
Entrepreneurial leadership & & .13 & & $.35^{* *}$ \\
\hline
\end{tabular}

Note. Standardized regression coefficients reported. $* p<.05, * * p<.01$. 
Table 3: Results of Hierarchical Regression Analyses (Mixed Modelling)

\begin{tabular}{lllll}
\hline & \multicolumn{2}{l}{$\begin{array}{l}\text { Affective Organizational } \\
\text { Commitment }\end{array}$} & Innovative Behavior \\
& Model 1 & Model 2 & Model 3 & Model 4 \\
\hline Tenure & $.04^{* *}$ & $.04^{* *}$ & -.01 & -.01 \\
Age & -.07 & .00 & .06 & .02 \\
Gender & -.16 & -.04 &.-01 & .05 \\
Pro-social motivation & $.40^{* * *}$ & $.27^{* *}$ & -.14 & -.16 \\
Creative self-efficacy & .05 & .04 & $.20^{*}$ & $.21^{*}$ \\
Entrepreneurial leadership & & .13 & & $.35^{* *}$ \\
Servant leadership & & $.47^{* *}$ & & -.22 \\
\hline
\end{tabular}

Note. Standardized regression coefficients reported. $* p<.05, * * p<.01$. 